\title{
CYCLIC RESPONSE OF SCALED LOW-RISE SHEAR WALLS WITH CONCEALED BRACINGS
}

\author{
CIKLIČNI ODGOVOR KONSTRUKCIJ IZ STRIŽNIH STEN, SPETIH \\ S SKRITIMI SPONAMI, V ZGRADBAH Z MAJHNIM ŠTEVILOM \\ NADSTROPIJ
}

\author{
Min Gan ${ }^{1,2}$, Ming Kang ${ }^{*}, 2$, Chuan Long ${ }^{1,2}$, Liren Li ${ }^{1,2}$ \\ ${ }^{1}$ School of Civil Engineering, Chongqing University, No. 174 Shazheng street, Shapingba District, Chongqing 400045, China \\ ${ }^{2}$ Key Laboratory of New Technology for Construction of Cities in Mountain Area (Chongqing University), Ministry of Education,
} Chongqing 400030, China

Prejem rokopisa - received: 2019-06-22; sprejem za objavo - accepted for publication: 2020-02-12

doi: $10.17222 / \mathrm{mit} .2019 .135$

To study the cyclic response of high-strength-concrete, low-rise shear walls of concealed, cold-formed, thin-walled, sectional steel trusses, two scaled specimens with concealed-angle steel bracings with axial pressure ratios of 0.52 and 0.60 were designed to analyze the anti-seismic performance of low-rise shear walls under different axial pressure ratios. A scaled specimen with an axial pressure ratio of 0.52 , but with a larger diagonal bracing area was designed to study the effects of increased area of diagonal bracing under a high axial pressure ratio on the anti-seismic performance. Low-cyclic repeated loading tests were conducted to determine the cracking loads, ultimate loads, and skeleton curves for each construct. The axial pressure ratio had significant effects on the cracking loads. Comparative analyses of the properties of the tested constructs, including the energy-dissipation capacity and the strength attenuation revealed that increasing the area of the diagonal bracing under a high axial pressure ratio can improve the anti-seismic performance of low-rise shear walls. This finding provides a basis for the optimized design of shear walls.

Keywords: low-rise shear walls, cold-formed sectional steel, anti-seismic performance, concealed bracing

Avtorji so v študiji raziskovali ciklični odgovor konstrukcije iz strižnih sten, izdelanih iz visoko trdnega betona, vgrajenih v zgradbe z majhnim številom nadstropij. Strižne stene so vertikalni konstrukcijski elementi v gradbeništvu, ki se upirajo bočnim silam v ravninah sten s striženjem in upogibanjem. Avtorji so stene povezali z mrežo spon iz hladno deformiranega gradbenega jekla. V ta namen so za analizo oblikovali dva vzorca strižnih sten, spetih s skritimi kotnimi jeklenimi sponami z aksialnim tlakom 0,52 in 0,60 ter analizirali njihove protipotresne lastnosti pri različnih razmerjih aksialnega tlaka. Prvi vzorec $z$ razmerjem aksialnega tlaka 0,52 toda $\mathrm{z}$ večjim diagonalnim presekom spone, je bil oblikovan $\mathrm{z}$ namenom študiranja vpliva povečanja preseka pri visokem aksialnem tlačnem razmerju na protipotresne lastnosti konstrukcije. Izvajali so malociklični preizkus obremenjevanja konstrukcije, da bi določili pogoje (obremenitve) pri katerih pride do nastanka razpok. Določili so tudi končne obremenitve pri katerih je prišlo do porušitev in skeletne krivulje vsake zgradbe posebej. Izbrano razmerje aksialnega tlaka je imelo pomemben vpliv na obremenitve pri katerih je prišlo do pojava razpok. Primerjalna analiza lastnosti testiranih zgradb, vključno s kapaciteto energije disipacije in zmanjševanja trdnosti je odkrila, da povečevanje diagonalnega spenjanja pri visokem razmerju aksialnega tlaka lahko izboljša protipotresne lastnosti strižnih sten v zgradbah z majhnim številom nadstropij. Te ugotovitve so osnova za optimizacijo oblikovanja strižnih sten.

Ključne besede: strižne stene, zgradbe z malim številom nadstropij, sestavljeni profili iz hladno deformiranega jekla, protipotresne lastnosti, skrite spone

\section{INTRODUCTION}

With the continued development of modern architectural technology and economy, innovative buildings are being designed and constructed. With increased height, there are increased requirements of high-rise building structures for a horizontal carrying capacity and a vertical bearing capacity. The intrinsic poor ductility of high-strength concrete limits its application in building structures with higher anti-seismic requirements. However, the excellent tensile ductility of profile steel offsets the shortcomings of high-strength concrete. Concrete covering strengthens the rigidity of the profile steel but has a poor fire-resistance offset. As the wall thickness of

*Corresponding author's e-mail:

kmingcqu@cqu.edu.cn (Ming Kang) the hot-rolled section steel is generally thicker than that of the cold-formed section steel, and its deformation capacity is better than that of the cold-formed section steel, under the same conditions, the hysteretic curve of the hot-rolled section steel shear wall is fuller than that of the cold-formed section steel shear wall, whose energy dissipation and deformation performance are also better. The use of built-in steel trusses can considerably improve the anti-seismic performance of high-strength concrete, but hot-rolled profile steel is expensive. The use of cold-formed thin-walled sectional steel instead of hot-rolled profile steel can substantially reduce the amount of steel required, thus decreasing the costs while ensuring sufficient anti-seismic performance. Given this benefit, studies of the anti-seismic performance of built-in, cold-formed, thin-walled, sectional steel, high-strength concrete can have economic significance. 
Many studies have examined concrete shear wall composite structures. Buddika et al. studied the seismic response of a concrete shear wall prepared by the posttensioning method from mixed prefabricated components. ${ }^{1}$ Tong et al. designed an I-shaped steel-reinforcement bar concrete wallboard composite shear wall on a $1 / 3$ scale and conducted a low-cyclic repeated test without the application of a vertical load. The result indicated that in the initial stage of loading, the stud connecting the concrete wallboard and the steel plate starts to yield, suggesting significant effects of this stud on the specimen's bearing capacity. ${ }^{2}$ J. H. Mun et al. ${ }^{3}$ discussed the shear resistance capability of gravity dams with construction joints. F. M. Ren et al. ${ }^{4}$ examined the stressstrain model and anti-seismic performance of steel-fiber composite boundary shear walls and found that that these shear walls exhibit excellent toughness. W. Kassem et al. ${ }^{5}$ proposed an analytical method to predict the shear strength and behavior of structural shear walls under the action of a single or cyclic load. A. Tuken et al. ${ }^{6}$ discussed an anti-seismic assessment for reinforcement-bar concrete shear walls. H. J. Lee et al. ${ }^{7}$ studied the anti-seismic strength of shear walls in a flexible seismic isolation structure. A. K. Bhowmick ${ }^{8}$ studied the antiseismic performance of center-hole circular steel-plate shear walls. P. D. Moncarz et al. ${ }^{9}$ introduced the theory and application of experimental model analyses in earthquake engineering.

To investigate anti-seismic measures for low-rise shear walls under a high axial pressure ratio, a low-rise shear wall component was designed with diagonal bracing of a high steel ratio. The effects of the ratio of the steel in the diagonal bracing on the bearing capacity of low-rise shear walls under a high axial pressure ratio were analyzed, with a comparison of the properties of failure mode, the hysteretic curve, the skeleton curve, energy-dissipation capacity, and the strength attenuation.

\section{TEST OVERVIEW}

\subsection{Test design}

\subsubsection{Specimen design}

According to the technical specification for the seismic tests of buildings (JGJ101-2015) ${ }^{10}$ three high-

Table 1: Detailed parameters of specimens

\begin{tabular}{|c|c|c|c|c|}
\hline \multirow{19}{*}{ wall } & Specimen number & SRHCW-2 & SRHCW-3 & SRHCW-4 \\
\hline & wall thickness (mm) & 120 & 120 & 120 \\
\hline & wall width $(\mathrm{mm})$ & 800 & 800 & 800 \\
\hline & clear height of wall & 650 & 650 & 650 \\
\hline & shear span ratio & 1 & 1 & 1 \\
\hline & edge component dimension $(\mathrm{mm})$ & $120 \times 160$ & $120 \times 160$ & $120 \times 160$ \\
\hline & edge component height $(\mathrm{mm})$ & 800 & 800 & 800 \\
\hline & horizontally distributed reinforcement bars in wall & $\phi 6.5 @ 100$ & $\phi 6.5 @ 100$ & $\phi 6.5 @ 100$ \\
\hline & $\begin{array}{l}\text { ratio of reinforcement of the horizontally distributed reinforcement } \\
\text { bars }\end{array}$ & $0.66 \%$ & $0.66 \%$ & $0.66 \%$ \\
\hline & vertically distributed reinforcement bars & $\phi 6.5 @ 120$ & $\phi 6.5 @ 120$ & $\phi 6.5 @ 120$ \\
\hline & $\begin{array}{l}\text { ratio of reinforcement bars in the vertically distributed reinforcement } \\
\text { bars }\end{array}$ & $0.55 \%$ & $0.55 \%$ & $0.55 \%$ \\
\hline & main reinforcement bar in the edge component & $6 \phi 8$ & $6 \phi 8$ & $6 \phi 8$ \\
\hline & profile steel in edge components & $60 \times 30 \times 2.2$ & $60 \times 30 \times 2.2$ & $60 \times 30 \times 2.2$ \\
\hline & ratio of reinforcement of main reinforcement bars in edge components & $1.57 \%$ & $1.57 \%$ & $1.57 \%$ \\
\hline & ratio of profile steel in edge components & $2.06 \%$ & $2.06 \%$ & $2.06 \%$ \\
\hline & stirrups of edge components & $\phi 6.5 @ 100$ & $\phi 6.5 @ 100$ & $\phi 6.5 @ 100$ \\
\hline & volume-stirrup ratio of edge components & $1.20 \%$ & $1.20 \%$ & $1.20 \%$ \\
\hline & cross section of diagonal bracing & $\begin{array}{c}\text { equilateral } \\
\text { angle steel } \\
\perp 30 \times 1.9\end{array}$ & $\begin{array}{c}\text { equilateral } \\
\text { angle steel } \\
\perp 30 \times 1.9\end{array}$ & $\begin{array}{l}\text { angle steel } \\
\perp 50 \times 30 \times 3\end{array}$ \\
\hline & steel ratio of diagonal bracing & $0.12 \%$ & $0.12 \%$ & $0.25 \%$ \\
\hline \multirow{5}{*}{$\begin{array}{c}\text { loading } \\
\text { beam }\end{array}$} & length $(\mathrm{mm})$ & 900 & 900 & 900 \\
\hline & width $(\mathrm{mm})$ & 300 & 300 & 300 \\
\hline & height $(\mathrm{mm})$ & 300 & 300 & 300 \\
\hline & main reinforcement bars & $4 \mathrm{C} 20$ & $4 \mathrm{C} 20$ & $4 \mathrm{C} 20$ \\
\hline & stirrups & $\phi 8 @ 100$ & $\phi 8 @ 100$ & $\phi 8 @ 100$ \\
\hline \multirow{5}{*}{$\begin{array}{c}\text { support- } \\
\text { ing } \\
\text { beam }\end{array}$} & length $(\mathrm{mm})$ & 1500 & 1500 & 1500 \\
\hline & width $(\mathrm{mm})$ & 350 & 350 & 350 \\
\hline & height $(\mathrm{mm})$ & 450 & 450 & 450 \\
\hline & main reinforcement bars & $8 \mathrm{C} 20$ & $8 \mathrm{C} 20$ & $8 \mathrm{C} 20$ \\
\hline & stirrups & $\phi 8 @ 100$ & $\phi 8 @ 100$ & $\phi 8 @ 100$ \\
\hline
\end{tabular}

Note: The reinforcement of SRHCW-1 is the same as that of SRHCW-2 and SRHCW-3 

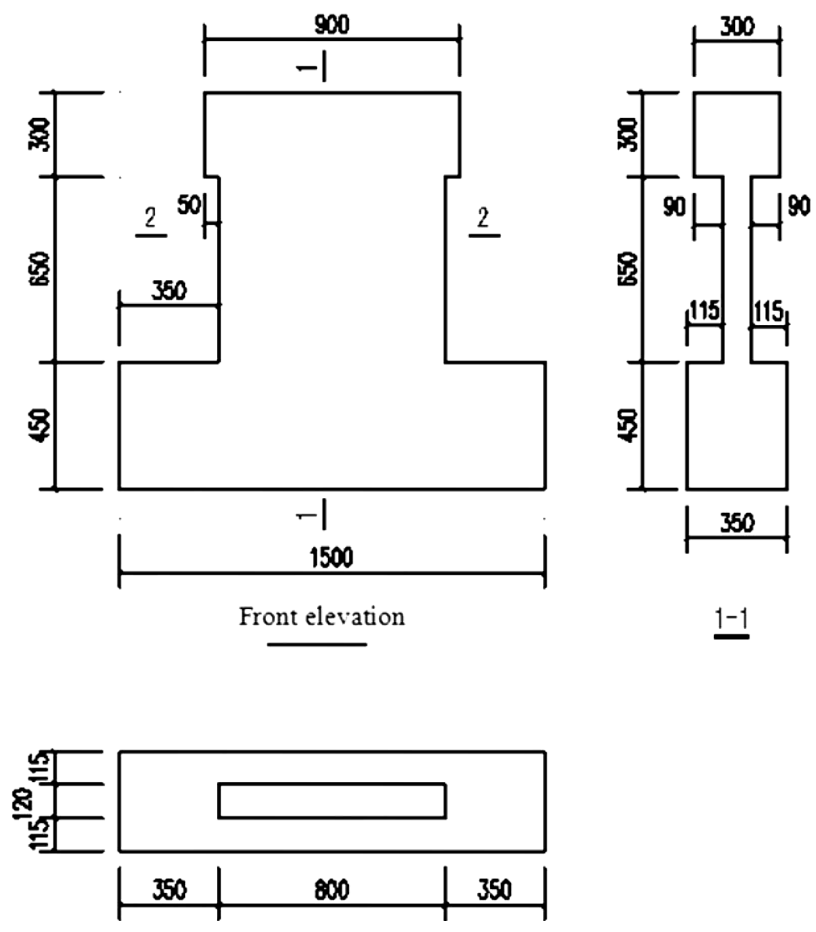

Figure 1: Specimen dimensions

strength-concrete, low-rise shear walls (SRHCW) were designed with internal cold-formed sectional steel trusses of the same external dimension with a $120 \times 800 \mathrm{~mm}$ wall cross-section with a 1/4 scale, as shown in Figure 1.

The three components, SRHCW1-3, used concealed bent angle steel, provided with concealed bracings for angle steel with a cross-section of $(30 \times 30 \times 1.9) \mathrm{mm}$ (SRHCW1 was designed and investigated by refer- ence $\left.^{11}\right)$. SRHCW-4 contained angle steel with a crosssection of $(50 \times 30 \times 3) \mathrm{mm}$. The detailed parameters of the specimens are shown in Table $\mathbf{1}$ and Figure 2.

\subsubsection{Concrete preparation}

The tests used high-strength concrete with a strength grade of $\mathrm{C} 60$ and the mix proportion indicated in Table 2.

Table 2: Mix proportion of C60 concrete

\begin{tabular}{|c|c|c|c|c|c|c|}
\hline $\begin{array}{c}\text { Material } \\
\text { components }\end{array}$ & Stones & Sand & $\begin{array}{c}\text { R42.5 } \\
\text { cement }\end{array}$ & $\begin{array}{c}\text { Fly } \\
\text { ash }\end{array}$ & Water & $\begin{array}{c}\text { Polycar- } \\
\text { boxylic } \\
\text { acid } \\
\text { water } \\
\text { reducer }\end{array}$ \\
\hline $\begin{array}{c}\text { mix } \\
\text { proportion }\end{array}$ & 1.85 & 0.90 & 1.00 & 0.08 & 0.26 & 0.01 \\
\hline $\mathrm{kg} / \mathrm{m}^{3}$ & 1119 & 546 & 602 & 50 & 165 & 7.5 \\
\hline
\end{tabular}

\subsubsection{Mechanical properties of the steel}

The reinforcement bars used in the test included $\phi 6.5$ horizontally distributed reinforcement bars, vertically distributed reinforcement bars, $\phi 8$ vertically and longitudinally load-bearing reinforcement bars in the edge components, diagonal bracing of the angle steel with 1.9 $\mathrm{mm}$ and $3 \mathrm{~mm}$ thicknesses (made of steel plates), and 2.2-mm-thick channel steel. All the reinforcement bars were hot-rolled, with the type being HRB 300. The diagonal bracing of the angle steel and the channel steel in edge components were cold-formed, thin-walled, sectional steel, the type of which is Q235. The mechanical properties of the steel are shown in Table 3.
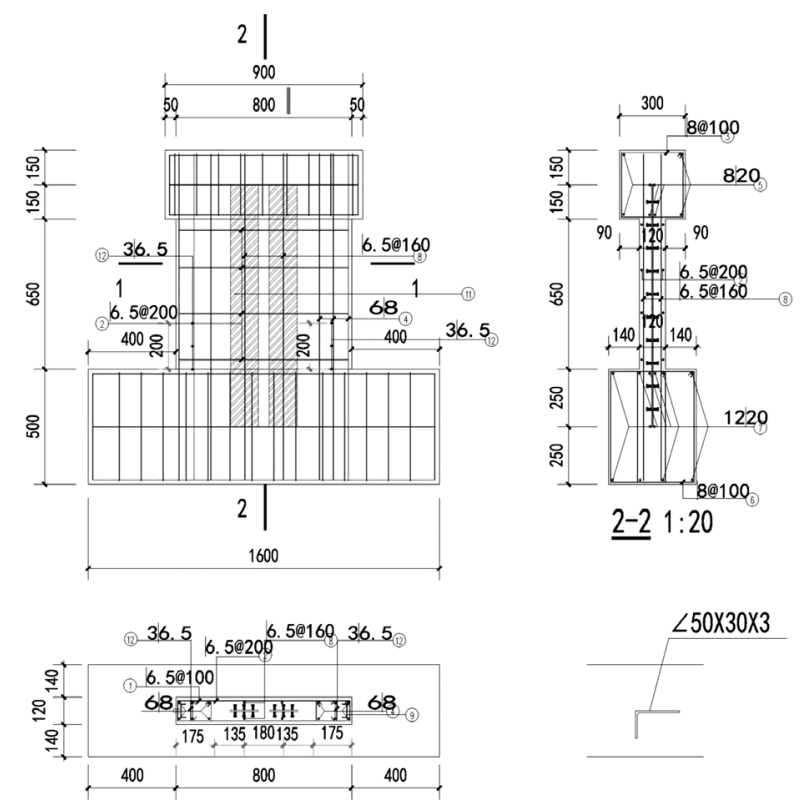

(b)

(a)

$\underline{1-1} 1: 20$

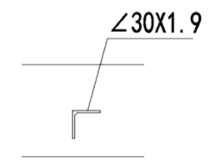

Figure 2: Detailed drawing for reinforcement of specimens: a) detailed drawing showing the reinforcement of SRHCW-1, SRHCW-2, and SRHCW-3, b) detailed drawing showing the reinforcement of SRHCW-4 
Table 3: Mechanical properties of steel and profile steel

\begin{tabular}{|l|c|c|c|c|c|}
\hline \multicolumn{2}{|c|}{ Type } & $\begin{array}{c}\text { Elasticity } \\
\text { modulus } \\
(\mathrm{Mpa})\end{array}$ & $\begin{array}{c}\text { Yield } \\
\text { strain } \\
(\mu \varepsilon)\end{array}$ & $\begin{array}{c}\text { Yield } \\
\text { strength } \\
(\mathrm{Mpa})\end{array}$ & $\begin{array}{c}\text { Ultimate } \\
\text { strength } \\
(\mathrm{Mpa})\end{array}$ \\
\hline \multirow{2}{*}{$\begin{array}{l}\text { diameter of } \\
\text { profile steel } \\
(\mathrm{mm})\end{array}$} & 1.9 & 206043.2 & 1892 & 389.8 & 409.8 \\
\cline { 2 - 6 } & 2.2 & 212491.7 & 1808 & 384.2 & 414.1 \\
\cline { 2 - 6 } $\begin{array}{l}\text { diameter of } \\
\text { reinforcement } \\
\text { bar (mm) }\end{array}$ & 6.0 & 204561.3 & 1786 & 365.5 & 425.5 \\
\cline { 2 - 6 } & 8.0 & 221100.0 & 1620 & 358.3 & 512.3 \\
\hline
\end{tabular}

\subsubsection{Measured concrete strength and axial pressure on specimens}

The four specimens in the test were prepared from concrete with a strength grade of C60. In this experiment, the concrete is poured in four different batches, corresponding to SRHCW-1-4. When the cured concrete reaches the required strength, the experiment is carried out. The corresponding $f_{\mathrm{cu}, \mathrm{k}}$ is $50.1 \mathrm{Mpa}, 59.3 \mathrm{Mpa}, 60.1$ Mpa and 59.2 Mpa. The standard value of the measured concrete strength $f_{\mathrm{cu}, \mathrm{k}}$ was consistent with the mean of the measured compressive strength of three $150 \mathrm{~mm}$ standard cubes, as shown in Table 4. In Table $4, f_{\mathrm{c}}$ is the design value of the compressive strength of the concrete, $f_{\mathrm{t}}$ is the design value of the tensile strength of the concrete, and $N_{\mathrm{t}}$ is the loading axial force applied in the test.

Table 4: Concrete strength and vertical load on specimens

\begin{tabular}{|c|c|c|c|c|c|}
\hline $\begin{array}{c}\text { Specimen } \\
\text { Number }\end{array}$ & $\begin{array}{c}\text { Design axial } \\
\text { pressure ratio }\end{array}$ & $\begin{array}{c}f_{\text {cu,k }} \\
(\mathrm{MPa})\end{array}$ & $\begin{array}{c}f_{\mathrm{c}} \\
(\mathrm{MPa})\end{array}$ & $\begin{array}{c}F_{\mathrm{t}} \\
(\mathrm{MPa})\end{array}$ & $\begin{array}{c}N_{\mathrm{t}} \\
(\mathrm{KN})\end{array}$ \\
\hline SRHCW-1 & 0.24 & 50.1 & 23.2 & 2.3 & 444 \\
\hline SRHCW-2 & 0.52 & 59.3 & 27.2 & 2.4 & 1140 \\
\hline SRHCW-3 & 0.60 & 60.1 & 27.5 & 2.4 & 1320 \\
\hline SRHCW-4 & 0.52 & 59.2 & 27.2 & 2.4 & 1140 \\
\hline
\end{tabular}

Note: Design axial pressure ratio is 1.2 times the loading axial force divided by the product of the concrete section area and the design value of the concrete axial compressive strength

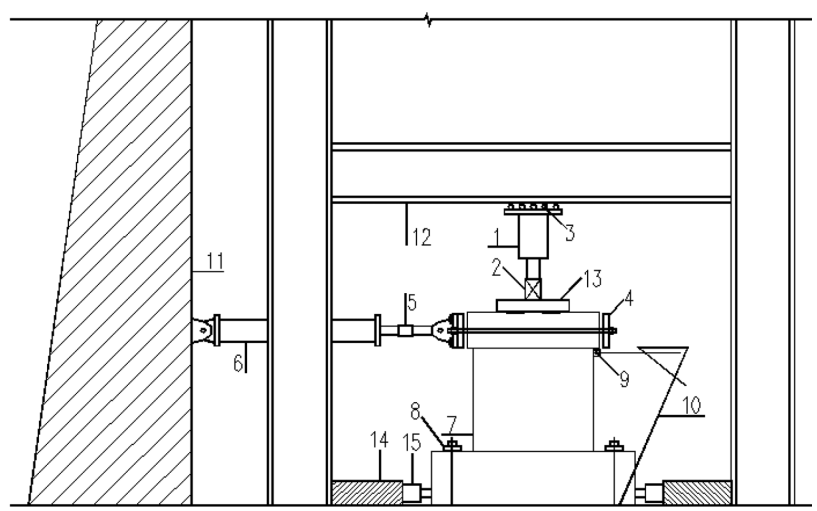

Figure 3: Loading device

1-150T vertical oil jack, 2-150T vertical sensor, 3-sliding support, 4-horizontal connection device, 5-150T horizontal sensor, 6-150T horizontal actuator, 7-specimen, 8-anchor bolt, 9-displacement meter, 10-angle steel shelf, 11-reaction wall, 12-reaction beam, 13-distribution beam, 14-support, 15-30T jack

\subsection{Test device and loading system}

\subsubsection{Test device}

According to the technical specification for seismic tests of buildings (JGJ101-2015) ${ }^{9}$, horizontal low-cyclic repeated quasi-static loading tests were conducted under the action of a stable and vertical axial force, with both vertical loading and horizontal loading. The vertical loading devices included a reaction beam, a vertical oil jack, and a jack pulley. The horizontal loading devices included a reaction wall, a horizontal actuator, and a horizontal connection device. The end of the horizontal actuator and the horizontal connection device were hinged. The vertical jack oil pump was manually controlled to ensure a stably applied vertical load. The horizontal actuator oil pump was manually controlled to achieve low-cyclic repeated horizontal loading. The loading devices are shown in Figure 3.

\subsubsection{Loading system of test}

Low-cyclic repeated quasi-static loading was performed in the test. The loading process was as follows:

(1) Preloading stage: A vertical load of $150 \mathrm{kN}$ was first applied at the top of the wall and then unloaded to 0 KN. This was repeated twice. Next, the load was increased to the pre-set value of the component under the appropriate axial pressure ratio (Table 4). The horizontal repeated load was pre-loaded with the same pre-set value for a micro cycle of $+20 \mathrm{kN} \rightarrow 0 \rightarrow-20 \mathrm{kN}$, to verify the normal operation of the experimental apparatuses.

(2) Loading stage of cracking load: After the microcycle was complete, the apparatus operated normally. The load was increased in the sequence $0 \mathrm{kN} \rightarrow 100 \mathrm{kN}$ $\rightarrow 150 \mathrm{kN} \rightarrow 200 \mathrm{kN} \rightarrow 250 \mathrm{kN}$, and then with $20 \mathrm{kN}$ as the gradient load until cracks occurred in the specimens. The positive load at the point of cracking was recorded, and then the horizontal load was unloaded to 0. Similarly, negative loading was performed to obtain negative cracks and determine the negative cracking load. Finally, the load was removed to zero.

(3) Displacement control loading stage: After the cracks occurred, the loading was controlled by displacement. Each level included two cycles. The first cycle was loaded and unloaded by trisection and the

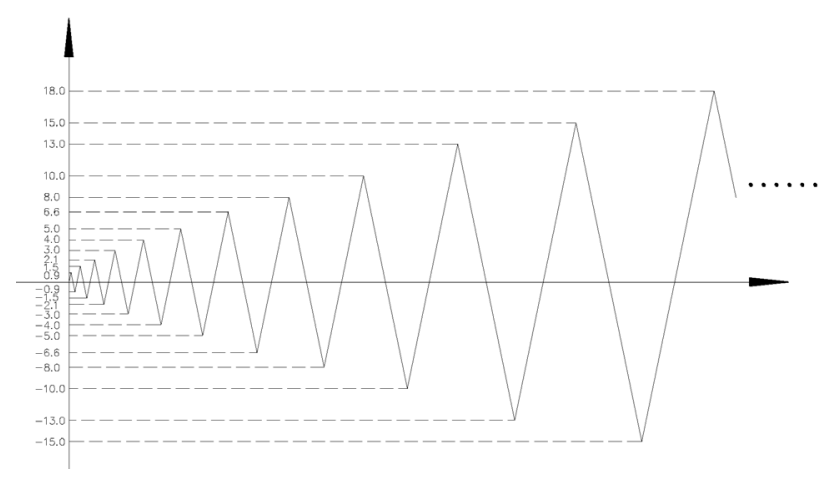

Figure 4: Loading system of the displacement control 
second cycle was loaded and unloaded at a single time. Failure of the specimen and a test finished were when the sample completely lost its vertical bearing capacity and its horizontal force decreased to $70 \%$ or less of the maximum horizontal force. See Figure 4 for the loading for each level in the displacement control.

\section{ANALYSIS AND COMPARISON OF THE TEST RESULTS}

\subsection{Analysis of modes and types of component failure}

In the test, the shear span ratio of each of the four specimens was 1.0. The designed axial pressure ratio of SWHCW-1 was 0.24 , and the axial pressure ratio for SRHCW-2 and SRHCW-4 was 0.52. The axial pressure ratio of SRHCW-3 was 0.60 . The specimen failure mode was determined by the appearance of cracks in the components, attenuation in the bearing capacity, and final failure mode. The final failure patterns of the specimens are shown in Figures 5 and 6. The failure process and characteristics are as follows:

(1) The concealed bracing for SRHCW-1 was single-leg $\angle 30 \times 1.9$ angle steel. In the low-cyclic repeated loading test, the specimen experienced eight complete cycles from loading to failure and failed at a displacement of $\Delta=22.0 \mathrm{~mm}$. The hysteretic curve was flat and the horizontal carrying capacity decreased slowly. When the component failed, the ultimate horizontal displacement was large, many oblique cracks developed in the wall, and the main oblique cracks were well developed. In the later stage, horizontal cracks occurred at the bottom of the wall. The main oblique cracks showed no significant signs of widening, and the horizontal cracks at the bottom of the wall became longer and wider when failure occurred. The compressed part in the corner of the specimen was crushed due to crack development and repeated loading and unloading. The compressed profile steel and diagonal bracing yielded and protruded under compression and the longitudinal tensile reinforcement

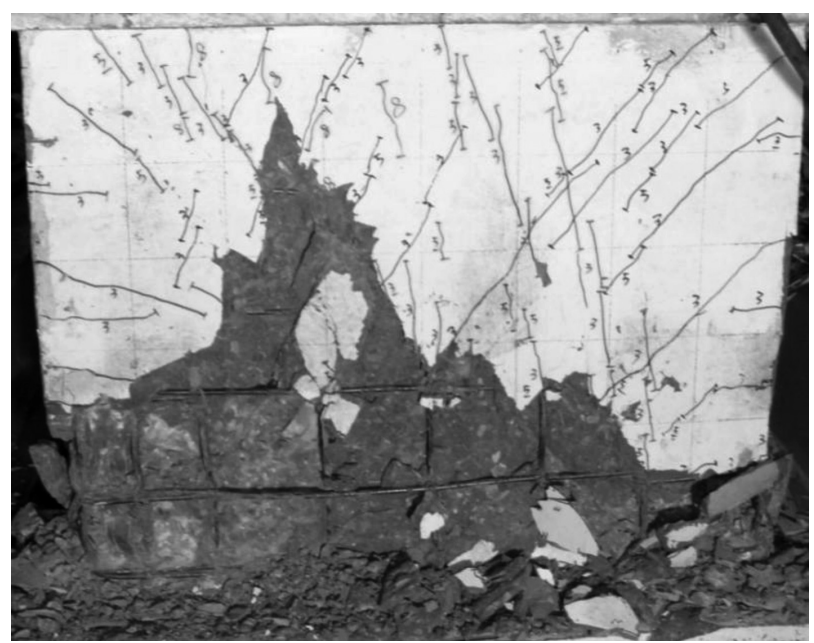

Figure 5: Final failure pattern of SRHCW-2 bars of the concealed column were broken. The above analysis indicated that the failure mode of SRHCW-1 was flexural shear failure.

(2) The reinforcement, edge profile steel, and concealed bracing of SRHCW-2 were the same as that of SRHCW-1, but with an increased axial pressure ratio of 0.52 , falling into the category of medium and high axial pressure ratios. The specimen was subjected to five complete cycles in the low-cyclic repeated loading test. During positive loading at a displacement $\Delta=13.0 \mathrm{~mm}$, the specimen failed and the horizontal carrying capacity declined slowly. However, the horizontal displacement increased sharply and the vertical bearing capacity was lost rapidly when the specimen failed. The specimen exhibited significant brittleness during failure, and many cracks developed in the wall. The main oblique cracks and the horizontal tensile cracks at the bottom of the wall did not widen significantly, and no slip cracks appeared at the bottom of the wall. The concrete in the corner of the component was crushed under repeated loading and the longitudinal load-bearing reinforcement bars and profile steel yielded under compression. A large amount of concrete spalled in the periphery of the compressed area in the corner, causing the component to rapidly lose its vertical bearing capacity and horizontal carrying capacity. Based on the above analysis, the failure mode of SRHCW-2 was small eccentric compression failure.

(3) The reinforcement of SRHCW-3, profile steel, and concealed bracing were the same as that of SRHCW-1 and SRHCW-2. However, the axial pressure ratio was increased to 0.60 , falling into the category of a high axial pressure ratio. In the low-cyclic repeated loading test, the specimen only experienced two complete cycles before failing at a displacement $\Delta=8.0 \mathrm{~mm}$. When the failure occurred, the flexural shear oblique cracks and main oblique cracks were well developed. Neither the main oblique crack nor the horizontal tensile cracks at the bottom of the wall had widened signi-

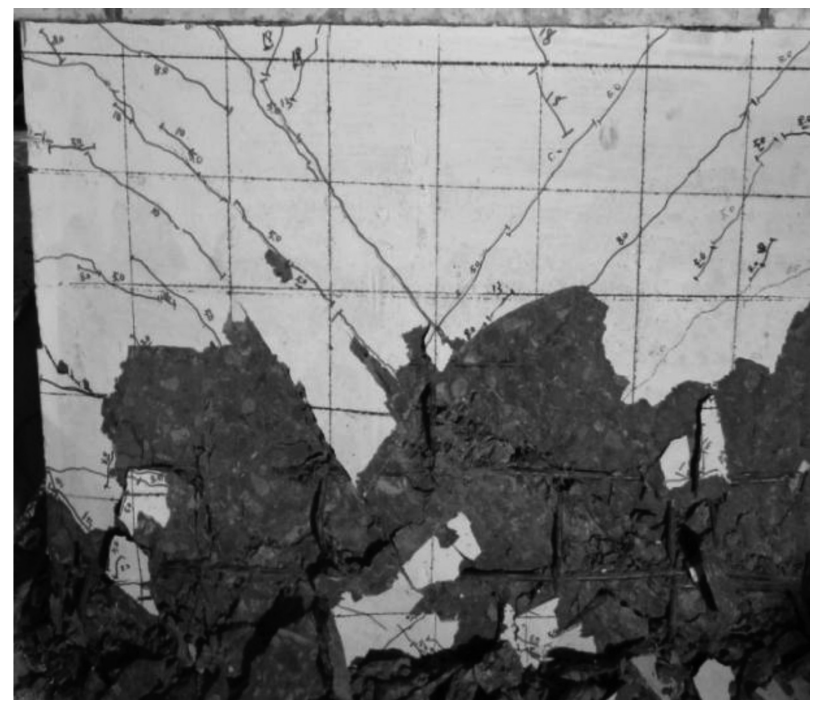

Figure 6: Final failure pattern of SRHCW-4 
ficantly, and the compressed area in the corner was crushed first. Subsequently, the concrete failure area extended towards the middle of the wall under the repeated action of the horizontal load. Finally, the concrete in the middle of the wall was crushed, causing rapid loss of the vertical bearing capacity and the horizontal carrying capacity with a poor deformation capacity. The above analysis indicated that the SRHCW-3 failure mode was small eccentric failure.

(4) The concealed bracing of SRHCW-4 was singleleg $\angle 50 \times 30 \times 3$ angle steel. The area of the diagonal bracing of SRHCW-4 was twice that of SRHCW-2 and both specimens had the same axial pressure ratio. In the low-cyclic repeated loading test, the specimen experienced eight complete cycles and failed at a displacement $\Delta=22.0 \mathrm{~mm}$. Its horizontal carrying capacity decreased slowly. The specimen exhibited excellent ductility and energy dissipation capacity at the time of failure and the cracks were well developed. The horizontal cracks between the wall bottom and the support were wide, and the oblique cracks showed no significant widening. With the increase in loading, the concrete in the two corners of the specimen was crushed successively. With the increase in displacement, the range of the compressed area increased. Finally, the concrete skin in the middle of the wall spalled on a large scale, with a loss of vertical bearing capacity and horizontal carrying capacity, marking the failure of the specimen. The above analysis indicated that the failure mode of SRHCW-4 was eccentric failure.

\subsection{Analysis of component skeleton curve}

Based on an analysis of the hysteretic curves of SRHCW-1-SRHCW4, it was concluded that the hysteretic curves of the four specimens have the following characteristics:

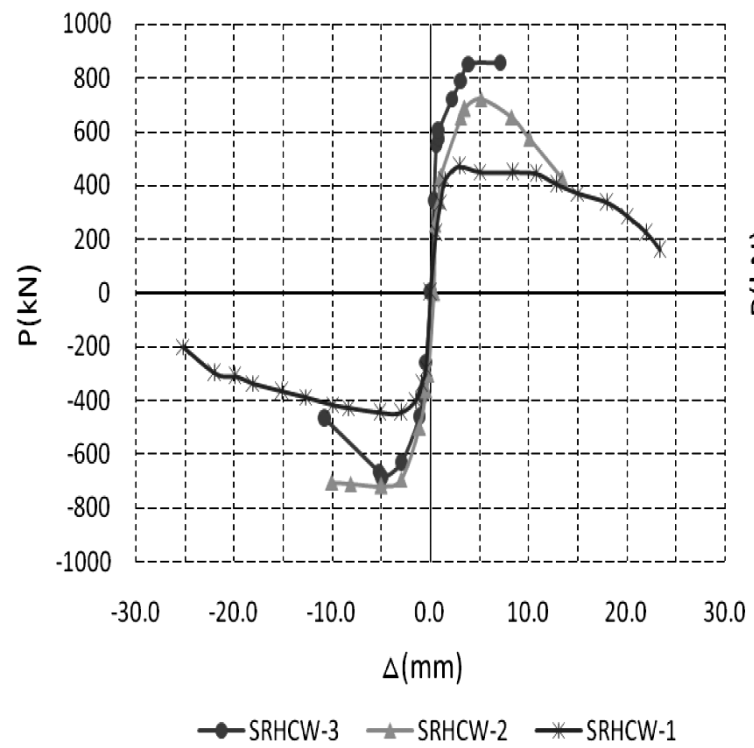

(1) In the initial stage, all specimens are in an elastic state and the unloading curve can return along the loading curve without any plastic deformation. In the stage from cracking to yielding of components, the area of the hysteretic curve enveloping is small. This is because the plastic deformation is small with a low percentage in the whole deformation; meanwhile, in this stage, the horizontal carrying capacity of each specimen increases with an increase in the displacement. After the specimen yields, with the increase in displacement, the horizontal carrying capacity of the specimen is declining gradually. The total deformation is dominated by plastic deformation. Thus, the hysteretic enveloping ring increases. The rigidness and horizontal carrying capacity of each specimen in the second cycle are lower than that in the first cycle.

(2) As can be seen in the hysteretic curves for the SRHCW-1-SRHCW-3 components, when the axial pressure ratio increases from 0.24 to $0.6, \mathrm{SRHCW}-1$ has a hysteretic curve with the best plumpness; SRHCW-2 has a hysteretic curve with moderate plumpness; SRHCW-3 has a hysteretic curve with the poorest plumpness. The SRHCW-3 component fails although it shows no significant signs of plastic deformation or a rheostriction effect. The three components can be arranged in a descending order in terms of ultimate displacement and energy-dissipation capacity, SRHCW-1 $>$ SRHCW-2 > SRHCW-3.

(3) Based on a comparison between SRHCW-2 and SRHCW-4, it has been found that as the area of concealed bracing in SRHCW-4 is twice that in SRHCW-2, it has a far plumper hysteretic curve and better plastic deformation and energy dissipation capacity under a axial pressure ratio of 0.52 than that of SRHCW-2.

The skeleton curve is obtained by smoothly connecting all the maximum stresses beyond the last loading in the stress and strain curves in the same direction of

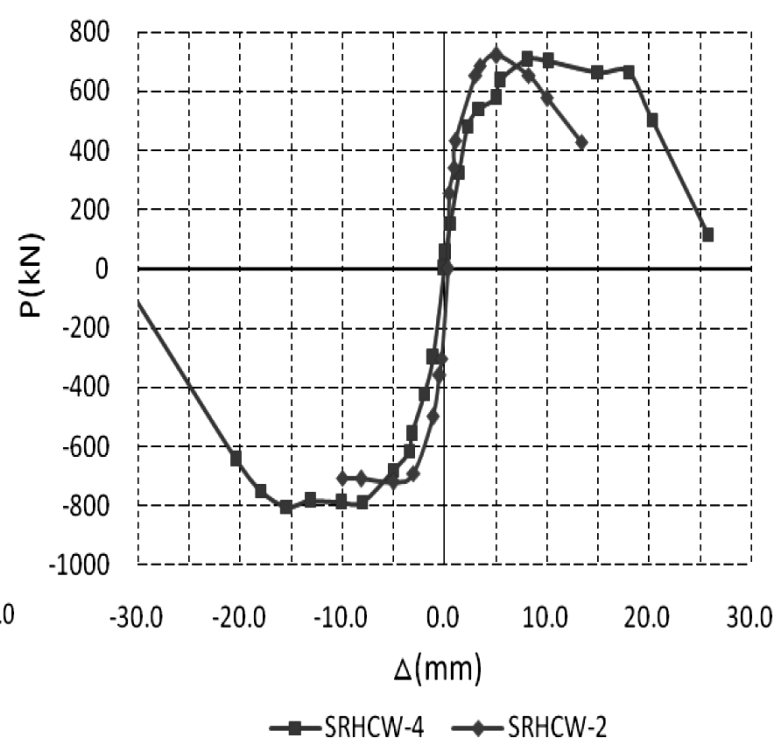

Figure 7: Skeleton curves of shear wall specimens: a) skeleton curves of SRHCW-1 and SRHCW3, b) skeleton curves of SRHCW-2 and 4 
loading (pushing or pulling). The skeleton curve is a locus curve of the maximum horizontal load for each cycle loading and can directly reflect the loading and deformation characteristics of the specimens in different stages. The skeleton curves enable a clear comparison of different specimens for rigidness, strength, energy-dissipation capacity, and ductility. The skeleton curves of SRHCW-1 to SRHCW-4 were determined and are shown in Figure 7.

An analysis of the above skeleton curves revealed the following characteristics:

(1) The initial rigidness of all four components is indicated as a straight line before cracking, suggesting that each component is in an elastic state before cracking occurs. The rigidness of each component starts to decline as the specimen cracks.

(2) As can be seen in Figure 7(a), the specimens can be arranged in a descending order by initial rigidness, SRHCW-3>SRHCW-2>SRHCW-1, suggesting increased initial rigidness with the increase in axial pressure.

(3) As can be seen in Figure 7a, the specimens can be arranged in a descending order by the ultimate horizontal displacement, in the order SRHCW-1 > SRHCW-2 > SRHCW-3, suggesting that with the increase in axial pressure, there is a continuous decrease in the ultimate horizontal displacement of each component. In the later stage, SRHCW-3 exhibits the fastest decrease in rigidness after it reaches the horizontal carrying capacity, SRHCW-2 shows a moderate decrease in rigidness, and SRHCW-1 shows the slowest decrease in rigidness. This suggests that the increase in axial pressure accelerates the decrease in component rigidity in the later stage and accelerates the component failure. The specimens can be arranged in order of decreasing ultimate horizontal carrying capacity, SRHCW-3 > SRHCW-2 > SRHCW-1, suggesting that increased axial pressure may be an effective strategy to increase the ultimate horizontal carrying capacity of the components.

(4) As can be seen in Figure 7b, the initial rigidness of SRHCW-2 was slightly higher than that of SRHCW-4, suggesting that increasing the area of diagonal bracing has little effect on the initial rigidness. In terms of the horizontal ultimate bearing capacity and the ultimate displacement, SRHCW-4 was better than SRHCW-2, suggesting that an increased diagonal bracing area can slightly increase the ultimate horizontal bearing capacity and effectively control the decrease in component rigidness in the late stage to provide sufficient ductility of the components.

In conclusion, increasing the axial pressure ratio can increase the ultimate horizontal bearing capacity and the initial rigidness of specimens. However, an increase in the axial pressure ratio decreases the horizontal ultimate displacement and accelerates the decline in rigidness in the late stage, thus decreasing the seismic resistance. Under a high axial pressure ratio, increasing the area of diagonal bracing can slightly increase the horizontal

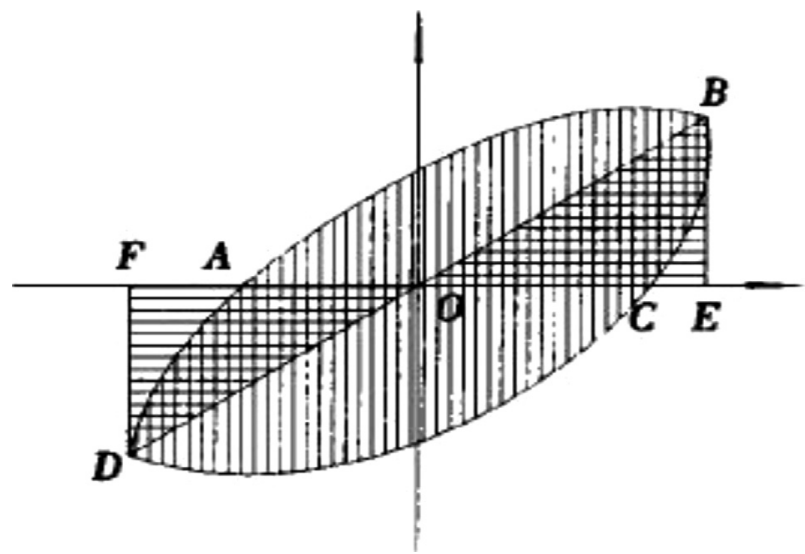

Figure 8: Diagram illustrating the computation of the equivalent viscous damping coefficient

bearing capacity, substantially increase the horizontal ultimate displacement, and control the decline in component rigidness in the late stage.

\subsection{Analysis of energy-dissipation capacity of the com- ponents}

The energy-dissipation capacity of a structure determines its anti-seismic performance level in earthquakes. The structural energy dissipation is mainly reflected by the plastic deformation of components in seismic responses, as indicated by the hysteretic curve. In this study, the equivalent viscous damping coefficient $h_{\mathrm{e}}$ and the energy-dissipation coefficient $\mathrm{E}$ were used to quantify the energy dissipation capacity of specimens. According to the technical specification for seismic tests of buildings (JGJ101-2015) ${ }^{9}$, E and $h_{\mathrm{e}}$ can be computed in each level of the cycle depending on the area of the hysteresis loop corresponding to the hysteretic curve.

Figure 8 presents the hysteretic curve for a certain cycle obtained by low-cyclic repeated loading. E and $h_{\mathrm{e}}$ are computed according to the following formula, which refers to the indicated parameters in Figure 8:

$$
E=\frac{S_{(\mathrm{ABCD})}}{S_{(\mathrm{OEB})}+S_{(0 \mathrm{FB})}} \quad h_{\mathrm{e}}=\frac{E}{2 \pi}
$$

Table 5 lists the energy-dissipation coefficients for SRHCW-1 to SRHCW4.

As can be seen in Table 5:

(1) With increased displacement, the energy generated in each cycle increased gradually, but the increase of the energy dissipation slows when the displacement reaches the peak.

(2) The specimens can be arranged in descending order of total energy dissipation, SRHCW-1 > SRHCW-2 > SRHCW-3. The results suggest that with the increase in axial pressure ratio, the energy-dissipation capacity of the components decreases. The energy-dissipation capacity of the components under a high axial pressure ratio is only $18 \%$ of that of components under a low axial pressure ratio. 
M. GAN et al.: CYCLIC RESPONSE OF SCALED LOW-RISE SHEAR WALLS WITH CONCEALED BRACINGS

Table 5: Calculated energy-dissipation capacity values of specimens

\begin{tabular}{|c|c|c|c|c|c|c|}
\hline Specimen Number & $\begin{array}{l}\text { Cycle } \\
(\mathrm{mm})\end{array}$ & $\begin{array}{l}\text { Energy dissipation } \\
(\mathrm{kN} \cdot \mathrm{mm})\end{array}$ & $E$ & $H_{\mathrm{e}}(\%)$ & $\begin{array}{c}\text { Cumulative energy } \\
\text { dissipation }\end{array}$ & Relative value \\
\hline \multirow{7}{*}{ SRHCW-1 } & 3 & 1531.2 & 1.07 & 17.1 & \multirow{7}{*}{31552.0} & \multirow{7}{*}{1} \\
\hline & 5 & 2088.0 & 1.11 & 17.7 & & \\
\hline & 8 & 3572.8 & 1.13 & 18.1 & & \\
\hline & 10 & 4431.2 & 1.22 & 19.4 & & \\
\hline & 13 & 5800.0 & 1.33 & 21.2 & & \\
\hline & 15 & 6449.6 & 1.32 & 21.2 & & \\
\hline & 18 & 7656.0 & 1.42 & 22.6 & & \\
\hline \multirow{4}{*}{ SRHCW-2 } & 3 & 1570.0 & 0.72 & 11.4 & \multirow{4}{*}{15236.0} & \multirow{4}{*}{0.48} \\
\hline & 5 & 2829.0 & 0.78 & 12.4 & & \\
\hline & 8 & 5219.0 & 1.10 & 17.5 & & \\
\hline & 10 & 5690.0 & 0.89 & 14.1 & & \\
\hline \multirow{2}{*}{ SRHCW-3 } & 3 & 1627.0 & 0.71 & 11.2 & \multirow{2}{*}{5673.0} & \multirow{2}{*}{0.18} \\
\hline & 5 & 4136.0 & 0.88 & 14.0 & & \\
\hline \multirow{7}{*}{ SRHCW-4 } & 3 & 1590.0 & 0.77 & 12.3 & \multirow{7}{*}{38443.0} & \multirow{7}{*}{1.22} \\
\hline & 5 & 2814.0 & 0.82 & 13.1 & & \\
\hline & 8 & 4664.0 & 0.80 & 12.7 & & \\
\hline & 10 & 5750.0 & 1.04 & 16.6 & & \\
\hline & 13 & 6754.0 & 1.12 & 17.8 & & \\
\hline & 15 & 7423.0 & 1.16 & 18.5 & & \\
\hline & 18 & 9448.0 & 1.18 & 18.8 & & \\
\hline
\end{tabular}

(3) For the energy-dissipation capacity, the specimens can be arranged in descending order as SRHCW-4 > SRHCW-1 > SRHCW-2. The data suggest that increasing the area of diagonal bracing can substantially increase the energy-dissipation capacity of components under the same axial pressure ratio. The horizontal carrying capacity of SRHCW-4 was higher than that of SRHCW-1, consistent with the slightly better energydissipation capacity of SRHCW-4 compared to that of SRHCW-1 in the same cycle.

\subsection{Analysis of the component-strength attenuation}

Strength attenuation, as defined here, means that the internal damage of the component that occurs in the first cycle of the low-cyclic repeated loading test causes a decrease in the horizontal carrying capacity in the second cycle. The ratio of the horizontal carrying capacity in the first cycle to the horizontal carrying capacity in the

Table 6: Strength-attenuation coefficients of specimens

\begin{tabular}{|c|c|c|c|c|}
\hline $\begin{array}{c}\text { Displacement } \\
(\mathrm{mm})\end{array}$ & SRHCW-1 & SRHCW-2 & SRHCW-3 & SRHCW-4 \\
\hline-18 & 0.89 & & & 0.91 \\
\hline-15 & 0.98 & & & 0.92 \\
\hline-13 & 0.98 & & & 0.93 \\
\hline-10 & 0.95 & 0.88 & & 0.92 \\
\hline-8 & 0.99 & 0.96 & & 0.95 \\
\hline-5 & 0.94 & 0.95 & 0.74 & 0.95 \\
\hline-3 & 0.93 & 0.96 & 0.98 & 0.97 \\
\hline 3 & 0.91 & 0.95 & 0.97 & 0.98 \\
\hline 5 & 0.94 & 0.93 & 0.93 & 0.97 \\
\hline 8 & 0.92 & 0.94 & & 0.95 \\
\hline 10 & 0.97 & 0.92 & & 0.95 \\
\hline 13 & 0.99 & & & 0.95 \\
\hline 15 & 0.94 & & & 0.94 \\
\hline 18 & 0.93 & & & 0.81 \\
\hline
\end{tabular}

second cycle was used to reflect the strength attenuation. The amplitude of the strength attenuation reflects the capacity of the component to resist deformation.

Based on the data in Table 6, it can be concluded that:

(1) Component strength attenuation generally decreases with the increase in cycle and the strength attenuation coefficient is minimum in the last cycle (approximating failure).

(2) In the cycle with a displacement of $3 \mathrm{~mm}$, the specimens can be arranged in order of increased strength-attenuation coefficient, SRHCW-1 < SRHCW-2 $<$ SRHCW-3. For displacements larger than $3 \mathrm{~mm}$, the specimens can be arranged in order of decreased strength-attenuation coefficient, SRHCW-1 > SRHCW-2 $>$ SRHCW-3, suggesting that a higher axial pressure ratio of the component leads to a smaller internal loss and a larger strength-attenuation coefficient under a small displacement. However, with the increase in the displacement, the strength-attenuation coefficient decreases, suggesting increased component-failure velocity.

(3) At the same displacement, SRHCW-4 has a higher strength-attenuation coefficient than SRHCW-2, indicating that increasing the area of the diagonal bracing can reduce the internal loss of the component and improve the capacity to resist the horizontal repeated load, thus increasing the strength-attenuation coefficient.

\section{COMPARISON OF MEASURED VALUES AND COMPUTED VALUES OF A COMPONENT'S BEARING CAPACITY}

The formula in Section 8.1.4 of technical specification for a steel-reinforced concrete composite structure 
Table 7: Measured values and computed values of components

\begin{tabular}{|c|c|c|c|c|}
\hline & SRHCW-1 & SRHCW-2 & SRHCW-3 & SRHCW-4 \\
\hline measured value of horizontal carrying capacity (KN) & 420.0 & 720.3 & 774.2 & 753.9 \\
\hline computed value $(\mathrm{KN})$ & 404.8 & 562.85 & 573.77 & 550.37 \\
\hline computed value/measured value & 0.96 & 0.78 & 0.74 & 0.73 \\
\hline
\end{tabular}

(JGJ138-2016) ${ }^{12}$ was used to compute the shear bearing capacity of the cold-formed, sectional steel, shear walls with concealed bracings. The computational results and measured values are shown in Table 7. As can be seen in Table 7, when the component has a low axial pressure ratio, the computed value shows good agreement with the measured value, with no significant difference. However, with an increase in the axial pressure ratio, the error between the computed value and the measured value increases, and all the computed values are smaller than the measured values. A higher axial pressure would lead to poorer ductility and anti-seismic performance of the components. Thus, the computation formula does not adequately consider the role of the axial pressure on the increase in the horizontal carrying capacity of the component. As a result, the formula further decreases the horizontal carrying capacity under a high axial pressure ratio, increases the safety margin for the horizontal carrying capacity of the low-rise shear wall, and properly overcomes the insufficient ductility of the low-rise, shear wall under a high axial pressure ratio.

\section{CONCLUSIONS}

By analyzing the failure mode, skeleton curve, energy-dissipation capacity, and strength attenuation of four scaled specimens, the results allow the following conclusions:

(1) Under a high axial pressure ratio, the component is mainly compressed. The component rapidly loses its vertical bearing capacity in a short period of time from concrete spalling to significant brittle failure. A higher axial pressure ratio leads to earlier and more abrupt failure. Under a high axial pressure ratio, increasing the area of the diagonal bracing can delay component failure but does not change the failure mode.

(2) The tests have shown that the ratio of steel in the diagonal bracings of the high-strength concrete low-rise shear walls is an important factor influencing anti-seismic performance. Under a medium or high axial pressure ratio, increasing the area of the diagonal bracing twofold neither changes the failure mode of the components nor substantially increases the horizontal carrying capacity, but improves the energy-dissipation capacity of components by $150 \%$.

(3) A comparison of the measured values of the shear bearing capacity of the cold-formed, sectional steel, shear wall with concealed bracings and the computed values derived according to the formula in the code reveals a large safety margin for the effects of diagonal bracings on the horizontal carrying capacity under a high axial pressure ratio.

\section{Acknowledgements}

This study was supported by the National Natural Science Foundation of China (Grant No. 51778087).

\section{REFERENCES}

${ }^{1}$ H. A. D. S. Buddika, A. C. Wijeyewickrema, Seismic Shear Forces in Post-Tensioned Hybrid Precast Concrete Walls, Journal of structural engineering, 144 (2018) 7, 04018086, doi:10.1061/(ASCE)ST. 1943-541X.0002079

${ }^{2}$ X. D. Tong, J. F. Haijjar, A. E. Schultz, Cyclic behavior of steel frame structures with composite reinforced concrete infill walls and partially restrained connections, Journal of constructional steel research, 61 (2005) 4, 531-552, doi:10.1016/j.jcsr.2004.10.002

${ }^{3}$ J. H. Mun, K. H. Yang, J. K. Song, Shear Behavior of Squat Heavyweight Concrete Shear Walls with Construction Joints, ACI structural journal, 114 (2017) 4, 1019-1029, doi:10.14359/51689785

${ }^{4}$ F. M. Ren, J. W. Chen, G. M. Chen, Y. X. Guo, T. Jiang, Seismic behavior of composite shear walls incorporating concrete-filled steel and FRP tubes as boundary elements, Engineering structures, 168 (2018), 405-419, doi:10.1016/j.engstruct.2018.04.032

${ }^{5}$ W. Kassem, A. Elsheikh, Estimation of Shear Strength of Structural Shear Walls, Journal of structural engineering, 136 (2010) 10, 1214-1224, doi:10.1061(ASCE)ST.1943-541X.0000218

${ }^{6}$ A. Tuken, N. A. Siddiqui, Assessment of Shear Wall Quantity in Seismic-Resistant Design of Reinforced Concrete Buildings, Arabian journal for science and engineering, 38 (2013) 10, 2639-2648, doi:10.1007/s13369-012-0482-0

${ }^{7}$ H. J. Lee, D. A. Kuchma, Seismic overstrength of shear walls in parking structures with flexible diaphragms, Journal of earthquake engineering, 11 (2007) 1, 86-109, doi:10.1080/13632460601033488

${ }^{8}$ A. K. Bhowmick, Seismic behavior of steel plate shear walls with centrally placed circular perforations, Thin-walled structures, 75 (2014), 30-42, doi:10.1016/j.tws.2013.09.027

${ }^{9}$ P. D. Moncarz, H. Krawinkler, Theory and application of experimental model analysis in earthquake engineering, Stanford university, Stanford 1981

${ }^{10}$ JGJ 101-2015 - Technical Specification for seismic tests of buildings. China standard press, Beijing

${ }^{11}$ Y. Yu, M. Gan, Y. Zhang, L. R. Li, H. K. Zhang, Experimental Research on Antiseismic Performance of High-Strength Concrete High-Shear Walls with Built-In Steel Plates, Advances in civil engineering, 2019 (2019), 4769404, doi:10.1155/2019/4769404

12 JGJ 138-2016 - Technical Specification for steel reinforced concrete composite structure, China standard press, Beijing 